\title{
Anti-Keynesian Views: Fiscal and Monetary Guidelines
}

\author{
Asst. Prof. Dr. Özlen Hiç Birol (Istanbul University, Turkey) \\ Assoc. Prof. Dr. Ayşen Hiç Gencer (Istanbul Aydın University, Turkey)
}

\begin{abstract}
In this article, we will cover the main anti-Keynesian views and macroeconomic systems that arose in the post Keynes period as well as their fiscal and monetary policy guidelines. As is known, the early Classical economists introduced a macroeconomic system based on the Quantity Theory and Say's Law resulting in automatic fullemployment equilibrium; and finally after 1929-1934 Great World Depression, the Keynesian System was introduced as a "revolution" (Keynesian Revolution) in theory and practice. As a result of the Keynesian policies implemented, European countries and the United States not only got over the Great World Depression but also in the years following the World War II, they have observed a fast and stable growth for a long time. Moreover, cyclical fluctuations have been controlled to a great extent. Even so, at the stage when the Keynesian System was introduced, anti-Keynesian views and macroeconomic systems were immediately introduced. Intense academic discussions between advocates of these views and the Keynesian economists have continued up until today. Meanwhile, many economists such as J.R. Hicks, R.F. Harrod, N. Kaldor, M. Kalesci, A.W. Philips, A. Hansen, P.A. Samuelson, E. Domar, J. Tobin, R. Solow, A.M. Okun, W. Helier, G. Ackler, F. Modigliani, and R. Musgrave and many others have developed and defended the Keynesian System from different aspects. We can characterize significant anti-Keynesian views and macroeconomic systems as the "Counter-Revolution".
\end{abstract}

\section{Introduction: The Main Anti-Keynesian Macroeconomic Schools}

Prominent anti-Keynesian views and systems could be classified under the following headings below:

\subsection{The Generalized Classical System}

The Generalized Keynesian System works with Keynesian macroeconomic parameters and functional relationships but it assumes full flexibility of prices and wages as well as perfect competition conditions in all markets and therefore refutes the Keynesian investment-saving discrepancy. Under these assumptions, the Generalized Classical System concludes that the economy would reach full-employment equilibrium automatically. According to this system, the unemployment would only be "voluntary", and there will be no involuntary unemployment. This system has been defended by Pigou at the very initial stage.

\subsection{The Neo-Classical Synthesis}

A fall in prices following a fall in wages will be resulting in "Pigou Effect". According to Don Patinkin, even if the Pigou Effect does not occur in the short-run and hence because of the dynamic effects and changes in the price expectations resulting from this price fall having negative effects on both investment and consumption expenditure; sooner or later, the Pigou Effect will definitely set in, providing automatic full-employment equilibrium in the macro-static analysis. In this case, theoretically, full-employment equilibrium will be attained automatically. However, since in the short run the negative effects of unemployment and price falls cannot be put up with when there is unemployment in the short run, the Keynesian policies will be implemented. This new approach combining the Keynesian and the Classical views is called the Neo-Classical Synthesis (Paya, 1994).

\subsection{Monetarism}

Monetarism or the monetary approach is introduced by Milton Friedman in 1963. This view comprises a more in-depth analysis of the money demand compared to the Keynesian System (Paya, 1994). It reaches Classical conclusions where the money supply is recommended to be fixed at a rate which corresponds to the growth rate; instead using the money supply as a policy tool for fine-tunings via concomitant changes in the money supply. It concludes that the fiscal policies are ineffective.

M. Friedman who introduced the monetary approach, has contributed to the Philips Curves analysis claiming that after long term changes in the price expectations, the effects changing the prices and wages would disappear, and the negatively sloped short-run Philips Curve in the Keynesian analysis would appear as a steep curve in the long-run; and in this case it is in vain to try to get unemployment rate below the "natural rate of unemployment.

Moreover, M. Friedman had strongly defended the idea that the government intervention, in general, would not be the right policy because it would cause deviations in the economy, thus what is actually required is to minimize the size of the government. From a theoretical point of view, even though this economic conservatism or economic liberalism would not necessarily be the result of monetarist view, in practice, both is interpreted together.

The importance M. Friedman attached to money demand and his analysis that the velocity of money in the long-run being constant, and accordingly, changes in money supply only be affecting the prices in the long-run even though they might affect the real parameters in the short-run-, do resemble the Quantity Theory of Money, 
and in particular, more of Irving Fisher's analyses rather than Alfred Marshall's. There is quite a distinct parallelism in between.

The following economists are renowned as monetarists: M. Friedman, Karl Brunner, Allan Meltzer, and Allan Walters.

\subsection{The New Classical School}

The New Classical School works with rational expectations hypothesis and full flexibility of prices and wages in all markets. The concept of rational expectations was first introduced by J.F. Muth (1961). Robert E.R. Lucas Jr. (1972) developed and popularized this hypothesis. Thomas Sargent, Neil Wallace, Robert Barro are other distinguished representatives of this school.

What is important in the New Classical School is first of all the assumption of full flexibility of prices and wages. As a result of this assumption, all markets will reach equilibrium, and the economy will automatically settle at the point of full-employment. Unemployment will be voluntary which will be denoted as "natural rate of unemployment".

According to rational expectations hypothesis, on the other hand, all the economic agents have full knowledge and information about all economic decisions - including government policies and their effects - and they take into account their future expectations in a right way. In this case, the government policies which will be expected and known to everybody will be already taken into account and the decisions on prices and quantities are formed accordingly, thus prices are formed in a complex fashion. In this way, the efficiency of any government policy is neutralized. Hence, as much as Keynesian financial policies, also the Monetarist monetary policies are ineffective. The only effective impact in economy seems to be "unexpected shocks" and accordingly "unexpected" or "shock" policy implementations.

The New Classical economists working with rational expectations follow M. Friedman in terms of "Philips Curve" (they accept that the Phillips Curve might be steep and even positively sloped) as well as in terms unemployment being voluntary. As a result, natural rate of unemployment will be prevail and it cannot be decreased through fiscal and monetary policies.

It is noticeable that the views of the New Classical School defending full flexibility of prices and wages leading to automatic full-employment equilibrium and the views of the Generalized Classical System are parallel with each other to a great extent.

It must be emphasized here that the rational expectations hypothesis is a separate assumption as opposed to the assumption of full flexibility of prices (and wages). The assumption of flexible prices leads to the automatic fullemployment equilibrium in the New Classical School. On the other hand, the rational expectations hypothesis leads to the conclusion that the previously known policies will be ineffective. Thus, J. Taylor accepting rational expectations but working with the rigidity of prices and wages reaches different conclusions. According to this model, Keynesian involuntary unemployment is inevitable. Hence, even if the rational expectations are accepted, fiscal and monetary policies become more efficient.

All these anti-Keynes views as well as macroeconomic systems, Monetarism in particular, and later on the rational expectations and the New-Classical School have had weight after 70s due to inflationary effects of the Vietnam War and the stagflation following 1973-1974 oil shock. In fact, the monetarist approach hence the economic conservatism both during Reagan era in the United States and Thatcher era in Britain affected the policy implementations for a while. However, it was not possible to prevent inflation; on the contrary, unemployment reached a new and higher dimension. Therefore, once more but this time with more cautious approach, a mix Keynesian and Monetarist policy implementation was adopted. On one hand, radical fiscal policies were implemented in order to prevent or decrease the budgetary gaps, on the other hand, monetary policies were applied for fine-tuning of economy, however this fine-tuning was not in the form of fixing the money supply in the long-run as recommended by the Monetarists. These policies were particularly based on the Keynesian analysis taken up in a broader perspective; that is to say, monetary policies being more effective in recession periods rather than fiscal policies.

In the following sections, all these anti-Keynesian views will be analyzed via the aid of LM-IS and/or AD-AS analysis. Thus, these policy recommendations will be summarized briefly. To be able to understand these antiKeynesian views, the Generalized Keynesian System will be discussed briefly in the next section.

\section{Keynesian System and Guidelines of the Keynesian Fiscal and Monetary Policies}

In this section, the "Generalized Keynesian System" assuming a low negative interest elasticity of the investment function featuring investment-saving discrepancy will be summarized via LM-IS and AD-AS analysis (Ackley, 1963; Hiç, 1994). 


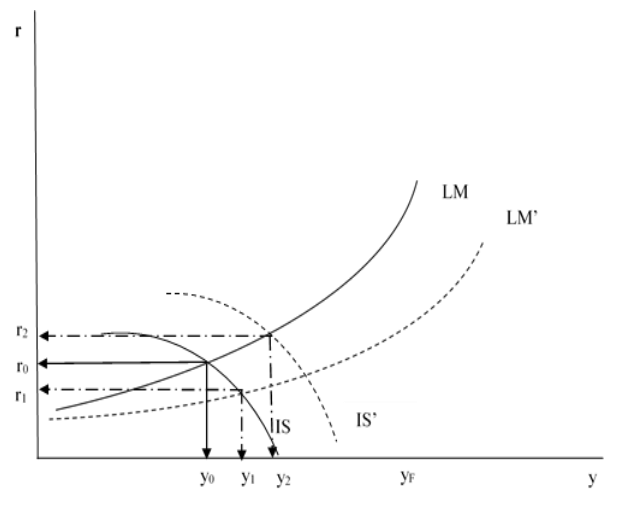

(a)

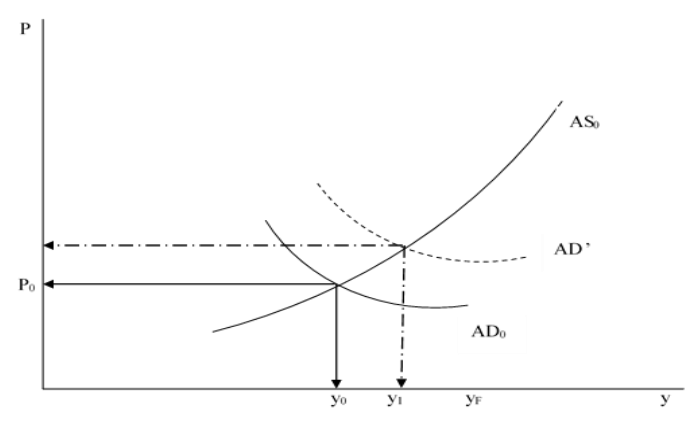

Figure 1

(b)

In Figure1 (a), the intersection of LM-IS curves shows the unemployment equilibrium which stems from the lack of effective demand. Either increasing the money supply and/or lowering the wages and prices (assuming that we ignore the fact that the fall in the prices would be having a "decreasing dynamic effect" on consumption and investments) would shift the LM curve to the right, eventually interest rates will decrease thus leading the real income to increase. Nevertheless, this possibility is limited; in other words, monetary policy is not much effective. Fiscal policies (increasing government expenditures and/or decreasing tax propensity) shifting the IS curve to the right will display a higher increase in the real income and the level of employment. Moreover, the fiscal policy tool can create a greater rate of increase than the monetary policy, especially for depression and low income and employment levels. In case of a recession and at higher income levels, this time, the monetary policy becomes more effective than the fiscal policies. This is why, today, in developed countries, fine-tuning of the economy is conducted through monetary policy rather than fiscal policy, and this also is explicable within the Keynesian System.

In Figure 1 (a), the analysis covers the aggregate demand elements. In Figure 1(b), the Keynesian System and its outcome are analyzed through the Aggregate Demand (AD) curve which gives the relationship between the price increases $(\mathrm{P})$ and real income or aggregate real demand (y); as well as the Aggregate Supply (AS) curve in between these two (Branson, 1979). AD is a negatively sloped curve. In the Keynesian System, AS appears to be a positively sloped curve. This can explained by the fact that the entrepreneurs can predict and calculate the price increases and real wages correctly whereas workers have money delusion (Branson, 1979). Alternatively, it is assumed that labor unions and workers will be consciously accepting a fall in their real wages against an increase in the effective demand and employment (Ackley, 1963). The outcome, in two different interpretations, increasing money supply and/or through fiscal policies, an increase in demand will be definitely raising both prices and real income, which means production. (Figure 1(b)). This is the underlying reason of raising the real income through the aggregate demand in the Keynesian System.

From here on, we can proceed to the Philips Curve Analysis. The above explained characteristic of the AS would reveal a negatively sloped Phillips Curve as a relation between the price increases and wage increases and unemployment rate (Branson, 1979). Whether fiscal policy or monetary policy to be implemented in Generalized Keynesian System and how effectively the AD-curve could be raised are already covered above.

\section{Generalized Classical System with Elastic Prices and Wages: Without Investment- Saving Discrepancy}

In the early discussions among the followers of the Keynesian System and the Classical System, A.C. Pigou accepted all the Keynesian parameters and functional relationships, however he assumed that negative interest elasticity of investments is high, hence refuted investment-saving discrepancy. Under the assumption of perfect competition conditions prevailing in the labor market and full flexibility of prices and wages, the equilibrium in economy, this time, will be reached automatically at the full-employment point. In the meantime, workers, like entrepreneurs, are presumed to guess and calculate the wage and price changes as well as the real wages correctly, that means they don't have money delusion. In such a system which is called the "Generalized Classical System", the equilibrium of the economy is summarized in Figure 2 by means of AD and AS curves (Pigou, 1941). 


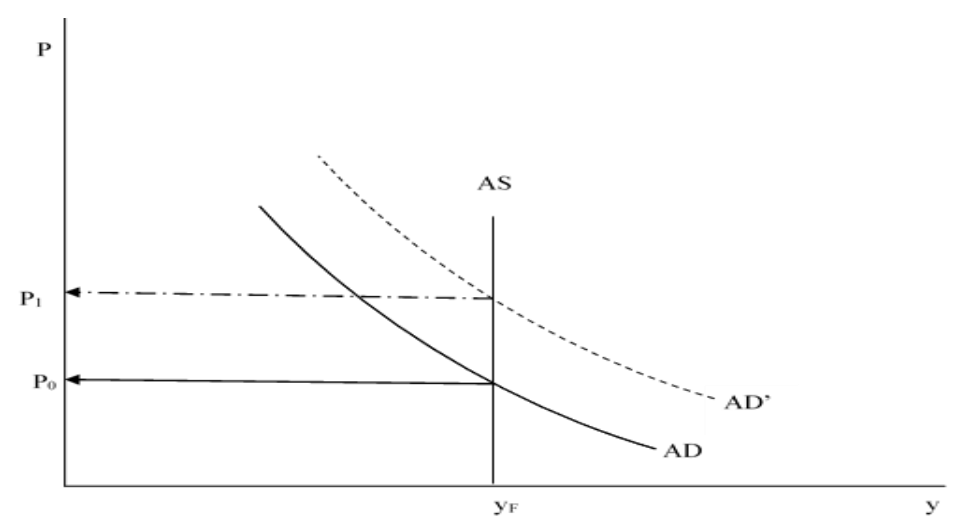

Figure 2

Under the above assumptions about the labor market and the supply of labor, the AS curve will be formed at one equilibrium regardless of the level of prices: full-employment real income level $\left(\mathrm{y}_{\mathrm{F}}\right)$. In other words, AS is a perpendicular line at $\mathrm{y}_{\mathrm{F}}$ level. In this case, $\mathrm{AD}$ will find its equilibrium though the prices at the $\mathrm{y}_{\mathrm{F}}$. As a result of an increase in the money supply, AD shifts to the right as AD', prices will increase from P0 to P1. Fullemployment real income equilibrium $\left(\mathrm{y}_{\mathrm{F}}\right)$, on the other hand, will not change. This is exactly like in the Marshallian Simple Classical System. Likewise, fiscal policies, too, will be increasing the interest rates, and the rise in interest will be causing a decrease in private investments thus changing the combination of real income and investment (Crowding-Out Effect). But ultimately, real income level will stay the same level, and with the increased interest rate, $\mathrm{AD}$ again shifts to the right and the general level of prices will rise.

Fiscal and monetary policy recommendations of this system are quite obvious; like in the Marshallian Simple Classical System; the money supply should be increased at a constant rate to keep the prices stable; money supply increase rate should be equal to or a little bit above of growth rate generated by the capital stock and technological advancement of the economy. The government should conduct only its classical functions, and accordingly, the government budget should to be small and balanced. Since full-employment equilibrium is reached automatically, there is no need for fiscal and monetary policies in order to increase the aggregate demand.

\section{Pigou Effect, Don Patinkin and the Neo-Classical Synthesis and Policies}

The fact that level of savings depends on wealth and negatively related to wealth, in case of a decrease in wages and prices, the real value of liquid wealth (money plus state bonds in the hands of people) will rise in the short-run and consequently, this will decrease the propensity to save (or raise the consumption); this is called the Pigou Effect (or Real Balance Effect) since it was first introduced by Pigou (1941). According to Pigou, even though, as a starting point, the Keynesian unemployment equilibrium is accepted; a fall in the wages and correspondingly a fall in the prices (ignoring the negative dynamic effects of price decreases on investments and consumption) will decrease the propensity to save. Thus, full-employment will be reached automatically equaling investment with saving at a positive interest rate at the full-employment real income level.

In Figure 3, the Pigou Effect is analyzed via IS-LM Curves: Initially, the economy is at the unemploymentequilibrium. If wages and prices are decreased sufficiently, through the Pigou Effect the economy will reach fullemployment.

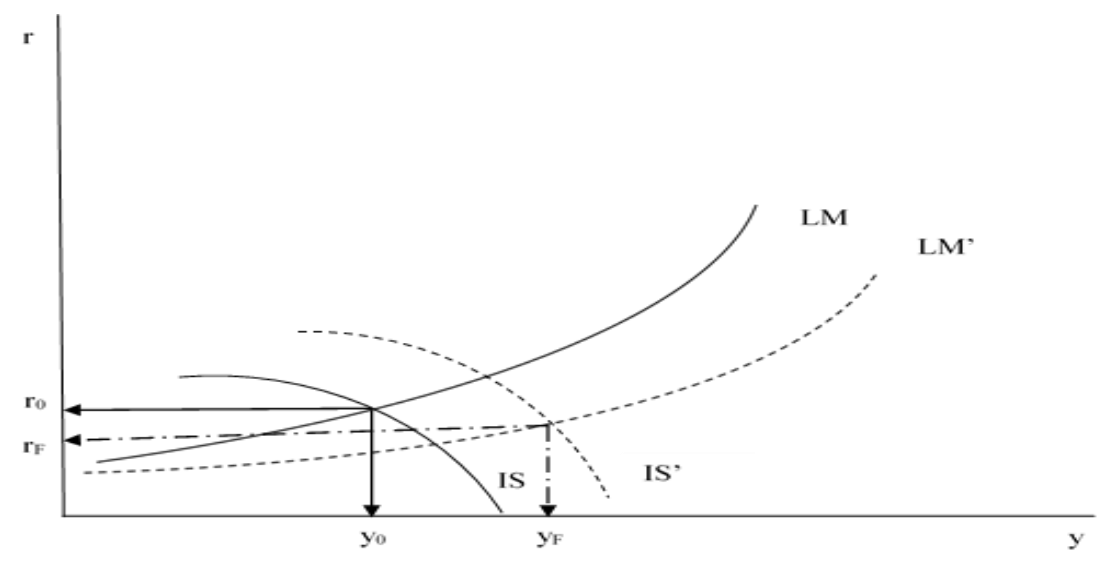

Figure 3 
Decreasing the wages and prices will first shift the LM-curve to the right because of the increase in real money supply: LM'. But this will not be sufficient to provide full-employment. However, because of the increase in prices raising, the real value of liquid wealth as a second wave (or Pigou Effect), the IS-curve will shift to the right as IS' to provide the new equilibrium at full-employment $\left(\mathrm{y}_{\mathrm{F}}\right)$.

Econometric studies conducted on the Pigou Effect shows that in the short-run such an effect is not encountered, and even it does exist, it is not that important or else the dynamic negative effects will not show up (Mayer, 1959; Hansen, 1951). However, Don Patinkin dealt with the Pigou Effect within an in-depth theoretical approach (Patinkin, 1956). According to Don Patinkin, within a static-analysis framework, the Pigou Effect will definitely will be observed and if the prices decrease sufficiently, full-employment equilibrium will be reached eventually $\left(\mathrm{y}_{\mathrm{F}}\right)$ and the equilibrium in Figure 3 will be reached not immediately in the short-run but in a longer term. Thus, the Classical automatic full-employment equilibrium assumption seems to be correct. On the contrary, Keynes' conclusion about the impossibility of automatic full-employment turns out to be wrong in terms of static-analysis. Although this issue is being correct from the theoretical perspective, in terms of shortrun policy recommendations, the circumstances are different: if in any period, the economy experiences an unemployment, decreasing the prices and wages as a policy recipe cannot be an applicable policy as it would take too long time to reach the full-employment equilibrium; prices would fall drastically and due to the dynamic effects of these price decreases for a long period of time, the employment will decrease even further. Neither the labor unions nor the entrepreneurs or even the government would like to go through all these drawbacks. And hence, in case of an unemployment problem, Keynesian policies should be implemented for the short-run. This compromise is called in economics literature "Neo-Classical Synthesis" (Paya, 1994). Maybe it was more appropriate to name it as "Neo-Classical-Neo-Keynesian Synthesis" like in the words of James Tobin.

\section{Monetarist Approach (Monetarism) and the Importance of Monetary Policy}

Monetarism was introduced by Milton Friedman as an opposing view to the Keynesian System.

The first study in Monetarism was about the velocity of money (V) being constant in the long run (Friedman and Schwartz, 1963). According to Milton Friedman, in the long run, the stability of V is more manifest than the Keynesian constant propensity to consume. But M. Friedman had introduced new principles to the Quantity Theory of Money (Friedman, 1956). M. Friedman, like Irving Fisher, has accepted for transition periods (Fisher, 1911), as V could change in a short-run the volume of money affects monetary and real parameters. But in the long-run, the effects of a change in the money supply on the real parameters disappear; as V being constant, an increase in the money supply will affect the monetary parameters only.

M. Friedman was not content with the concepts of idle and active balances of the Keynesian money demand; he dealt with the money demand in a more comprehensive way. Yet, it is possible to simplify M. Friedman's detailed money demand analysis into a simple Quantity Theory equation (Paya, 1994).

In the context of this article it is not seen as a necessity to study M. Friedman's money demand and money supply functions in detail. Money demand could be explained in summary via the equation below:

$$
\mathrm{M} / \mathrm{P}=\mathrm{k}(\mathrm{y}) \text { or } \mathrm{M} . \mathrm{V}=\mathrm{P} . \mathrm{y}
$$

In the Classical System, (y) represented all goods and services produced (real income); Marshallian k or the velocity of money (V) was constant in the short-run. In Monetarism, however, (y) represents the sum of "permanent" income. In the short-run, Marshallian k or the value of V might change.

Additionally M. Friedman had identified the function of money supply entailing people's attitudes towards money and the reserve rates of banks. Government or the monetary authorities could alter the amount of the base money (Friedman, 1956; Paya, 1994).

These views of M. Friedman would have taken him to a position to recommend for the Central Bank to finetune the money supply, in a more appropriated base money quantity according to economic cycles. But the fact that the money demand is vague and hard to predict prevented M. Friedman from making such a recommendation. On the contrary, M. Friedman advised exactly like the other followers of the Classical Quantity Theory that the money supply (base money quantity) should be increased at a constant rate in parallel with growth rate. According to M. Friedman, the most persistent social problem is not unemployment but inflation. Inflation is a monetary event, and it is only possible to avoid it through the controlling the money supply.

M. Friedman introduced the concept of "natural rate of unemployment - NRU" in terms of employment and unemployment. This is in one respect the employment rate at which the economy experiences only voluntary unemployment rather than open unemployment stemming from the lack of effective demand. Yet, we can also add the frictional unemployment and the structural unemployment at the sectoral level to this voluntary unemployment.

In the Phillips Curve analysis, M. Friedman constructed a negatively sloped short-run Phillips Curve crossing (x)-axis at NRU-point, however, he also claimed that the long run Philips curve will be showing up at NRUpoint as a perpendicular line. This is shown in Figure 4. 


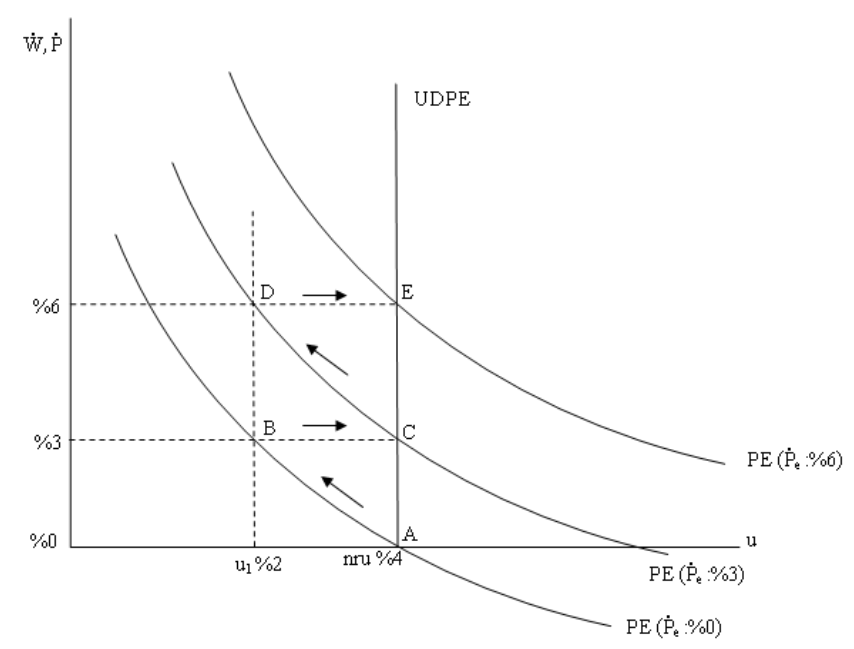

Figure 4

Let us assume that NRU is $4 \%$. And productivity increase throughout the periods is, say, zero. In this case, an increase in cash wages $(\dot{W})$ will be equal to the increase in the general level of prices $(\dot{P})$. If the $(\mathrm{y})$-axis describes $(\dot{W})$, the short-run Philips Curve with a price increase expectation $(\dot{P} e)$ of $0 \%$ will be a negatively sloped curve crossing $\mathrm{X}$-axis at the NRpoint. Now, if we increase the aggregate demand via an increase in the money supply or via monetary policies, the new equilibrium will increase upwards from point A to point B in the short-run. However, as a result of this, the price increase will be, say, 3\% as shown in Figure 4 (which is equal to the increase in the cash wages). In this case, workers will notice that there is a decrease in their real wages and according to their new price increase expectations of $(\dot{P} e=3 \%)$, a new short-run Philips curve will be formed. Even in this case, the equilibrium will shift from point $\mathrm{B}$ to point $\mathrm{C}$. That means it is a comeback to NRU again. As it is seen in Figure 4 ( $\mathrm{Pe}=6 \%$ etc.), this process will continue even if the government insistently creates further increases in demand. Hence, for the long-run, there will be a perpendicular line at NRU (the long-run Phillips Curve) and in this case, it will be pointless trying to decrease the unemployment rate by increasing the demand. Thus, according to M. Friedman, the equilibrium of economy could be represented in Figure 5 by means of aggregate demand (AD) and aggregate supply (AS) (Klamer, 1984).

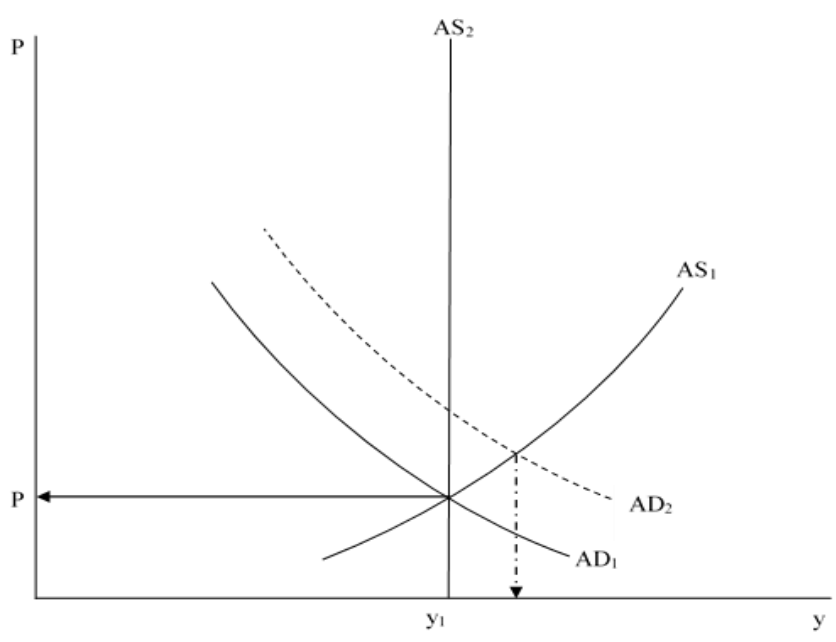

Figure 5

Let us assume that the economy is at equilibrium at AD1, AS1, P and y1 where y1 represents the real income level corresponding to natural unemployment rate. Now, say that government raises the aggregate demand to $\mathrm{AD} 2$ level. In this case, prices as well as real income will increase in the short-run, while unemployment will decrease (the intersection of AS1 and AD2). But in the long-run, the price expectations will change and as a result of workers' reassessment of price and wage increases, the economy will end up at AS2 in the long-run. Hence, any increase in the aggregate demand will not be increase real income and employment in the long-run, it will only raise prices.

In the Philips Curve and AD-AS analysis, the underlying assumption is that the workers will correct their expectations in the next period, in other words, a turn-back from the delusion. In the first period, workers have delusion about the price increases and real wages but then they correct their mistake. This is called "adaptive 
expectations". Although M. Friedman worked with "adaptive expectations" New Classical economists work with "rational expectations".

Additionally, M. Friedman refuses the efficiency of fiscal policies in terms of changing the demand, and he opposes to the Keynesian policy recipes.

As is was mentioned before in the introduction part, in terms of economic policies, M. Friedman happens to be conservative just like the old Classical economists; he is in favor of economic liberalism. Thus, the government intervention on social or other grounds will result in wrong outcomes, even backlash. That is why the government has to be small, and its budget should be balanced.

M. Friedman's monetary approach was accepted and became widespread only in 70s as a result of budget gaps that was brought about by the Vietnam War and also after 1973-1974 oil shock. Thus, for a while, in the United States (during Reagan era) and in Britain (during Thatcher era), monetarist policy recommendations were implemented. But the unemployment rate increased, and inflation was not prevented. Nevertheless, even today, both in academic circles and in political circles, beside the Keynesian approaches, the monetarist views seem to have an important weight. On the other hand, M. Friedman's emphasis on the monetary policy has challenged the Keynesian economists to reevaluate and better appreciate monetary policy. The fact that M. Friedman looks down on fiscal policy is not acceptable because fiscal policies will affect the real income level shifting the aggregate demand, and through the changes in the interest rates, they will bring about "crowding-out effect" for private investment.

\section{Rational Expectations, Efficiency of the New Classical Views and Economic Policies}

In 70s, besides Monetarism, a new and distinct anti-Keynesian view was introduced: The New-Classical School working with rational expectations. As mentioned in the introduction part, this school, pioneered by Lucas, is based on two important assumptions.

The first one is rational expectations. According to this hypothesis, all economic agents are have full access to all information, and they have knowledge about what kind of policies government will be implementing as opposed these data, and eventually they make their mind about prices and quantities taking into consideration all this information, policies and their effects. Thus, rational expectations based on these information and rationality are part of the establishment process of prices in the markets. As opposed to the rational expectations, in the theory of adaptive expectations, workers err in their cash wages in the first period, but this mistake will be corrected later. Particularly workers correct their demand for cash wages after seeing that their real wages had decreased as opposed to price increases. This process lead to a long term Philips which is perpendicular at NRUpoint and to a long-run AS which is, like in Generalized Classical System, again perpendicular at NRU-point. In the Generalized Keynesian System though, the mistakes in calculations are not corrected leading to a positive slope Aggregate Supply Curve.

The second assumption is flexible prices and wages; the New-Classical economists assume that all prices and wages in economy are flexible. In this case, the equilibrium in the economy will be reached through price changes within the Walrasian general equilibrium approach. This equilibrium is full-employment equilibrium due flexibility of prices and wages; and there will be only voluntary unemployed (or rather, NRU). As opposed to the New-Classical School, in the Keynesian System, even if the prices and wages fully rigid, they are assumed to be partly rigid especially downwards. This leads to the existence of involuntary (open) unemployment besides the voluntary unemployment in the Keynesian System.

Followers of rational expectations and New-Classical School attribute the de facto high unemployment rate in economies to two important reason. First reason is that there is a "natural" rate of unemployment prevailing in the economy and the Philips Curve is being perpendicular because of rational expectations. The New Classical economists even mentioned the possibility of a positively sloping Philips Curve. The second reason of a high unemployment rate might be that the economic-agents while taking decisions might not always be furnished with full information and knowledge hence they are bound to make mistakes.

The equilibrium in the economy, according to the New Classical economists working with rational expectations, is represented in Figure 6 by means of AS and AD curves (Klamer, 1984).

In the initial period, assume that economy is at equilibrium at real income level $\left(\mathrm{y}_{\mathrm{nru}}\right)$ at the intersecting point of aggregate demand $\mathrm{AD}_{0}$ and aggregate supply $\mathrm{AS}_{0}$. Now, through fiscal and monetary policies, assume that the aggregate demand shifts upward to $\mathrm{AD}_{1}$. As all the individuals have full information, the $\mathrm{AS}$ curve will increase to $\mathrm{AS}_{1}$. This way, the equilibrium real income level $\left(\mathrm{y}_{\mathrm{nru}}\right)$ will remain the same. Lack of information and certain delays might slow down this process a bit and in the meantime the equilibrium income level could be different for a short period of time. In case individuals have full information and there are no delays, then we will be ending up with a perpendicular and continuous AS-Curve at $\mathrm{y}_{\text {nru. }}$. 


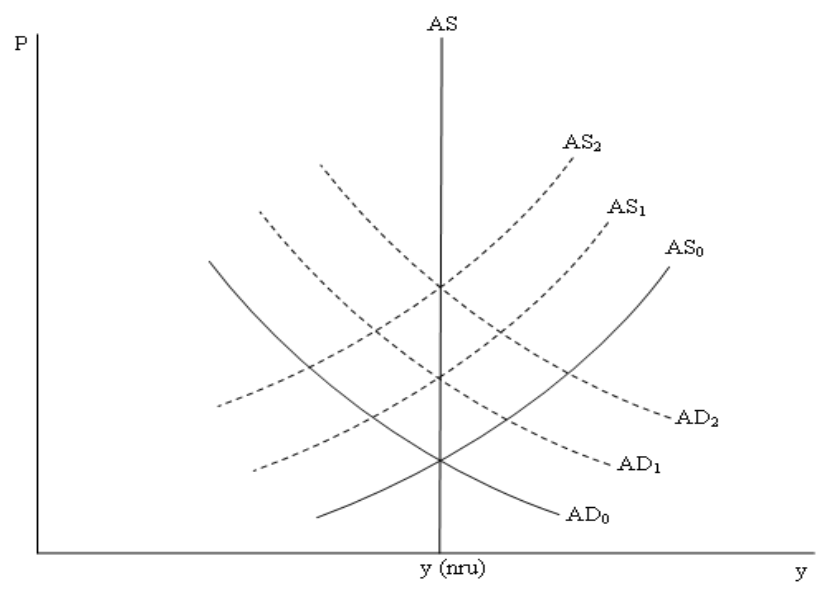

Figure 6

New Classical School working with rational expectations reflects a stricter and limited policy recommendation regarding efficiency than the Monetarists. This is so because according to the New Classical economists, in case the government tries to implement a policy, it will be known beforehand, hence the economic agents will already be taking the effects of these policies into account while they decide on their economic activities. Therefore, any policy will be ineffective. This criticism is directed as much towards the Keynesian fiscal and monetary policies as towards the Monetarist monetary policy. In this case, in order to have efficient policies to be implemented by the government, these should not been known beforehand, that means they have to come in the form of a "shock". In fact, the members of this school led by Lucas, are very suspicious of the policies implemented by government and they prefer that government will not intervene in economic activities at all. This is so because according to them, it is very likely that the politicians may be mistaken and their motivation might be to strengthen their own political positions rather than fixing the economy (Klamer, 1984).

Systematic studies of expectations by the New Classical economists, under the assumption of rational expectations, created a buzz in 70s in the United States. Many young economists were drawn towards the NewClassical approaches working with sophisticated mathematical models. However, neither the New-Keynesian nor the Post-Keynesian economists do recognize the two fundamental assumptions of the New Classical School as realistic. According to them, it would be not likely that everybody in economy could be having full information and estimate the relevant economic policies correctly in advance and without any mistake. This would be unrealistic. In real life, there will be always some cases of lack of information or some margin of error. Furthermore, it would not even make sense trying to have full information in an environment where prices do go through drastic changes. Secondly, through full flexibility of prices and prices, all markets reaching the equilibrium through the Walrasian general equilibrium cannot be accepted as realistic either. Prices and wages would definitely rigid to an extent. Here, it is necessary to emphasize that the second of the Neo-Classical fundamental assumptions is more important. This is so because the Keynesian policies become more effective in the models which work with the assumption of rational expectations but accept rigidity of prices and wages (Phelps and Taylor, 1985).

This study would bring us to a conclusion that the Keynesian System is still valid.

\section{References}

- Ackley, Macroeconomic Theory, 1963.

- Blaug, Economic Theory in Retrospect, 4th Edition, 1988.

- Branson, Macroeconomic Theory and Policy, 1979.

- Dronbusch and Fisher, Macroeconomics, 1990.

- Fisher, The Purchasing Power of Money, 1911.

- Friedman, “The Quantity Theory of Money: A Restatement”. M. Friedman, ed., Studies in the Quantity Theory of Money, in 1956.

- ᄀ , Money, Interest and Prices, 1956.

- Friedman and Schwartz, A Monetary History of the United States (1867-1960), 1963.

- Hansen, “The Pigovian Effect”, Journal of Political Economy, December 1951.

- Hiç, Para Teorisi ve Politikası, 1994.

- Klamer, The New Classical Macroeconomics, 1984. 
- Mayer, "The Empirical Significance of the Real Balance Effect", Quarterly Journal of Economies, May 1959.

- Patinkin, "Price Flexibility and Full Employment", American Economic Review, September 1948.

- Paya, Para Teorisi ve Politikasi, 10th Section, 1994.

- Phelps and Taylor, "Stabilizing Properties of Monetary Policy under Rational Expectations", Journal of Political Economy, 1985.

- Pigou, Employment and Equilibrium, 1941.

- Samuelson and Nordhaus, Economics, 1th edition, 1985. 